\title{
WOMEN AND CHURCH LEADERSHIP REVISED: THE IMPLICATIONS OF A MISSIONAL ECCLESIOLOGY AND A THEOLOGICAL ANTHROPOLOGY
}

\author{
AMJ Leene and HJ Hendriks ${ }^{1,2}$ \\ Practical Theology and Missiology \\ Stellenbosch University
}

\begin{abstract}
The position of women in church leadership positions is still a burning issue. A key aspect of the issue is sexual identity and its implication for women in church leadership structures. Changing contexts and shifting paradigms have led, amongst others, to a rediscovery of the role of the Trinity. This in turn led to new perspectives on ecclesiology, i.e. a missional ecclesiology, as well as new perspectives on a theological anthropology. The unity and diversity in the Trinity form the basis of human identity irrespective of sexuality. As such the church offices are understood in the light of the missio Dei and need both men and women in leadership.
\end{abstract}

Key Words: Women in Leadership; Trinity; Missional Ecclesiology; Anthropology; Authority

\section{Introduction}

In many Reformed Churches, the offices have recently been opened for women. However, this is not the case in all denominations. In this regard, the reasoning often is far from thorough and extensive. Lim (2000:288) opines that, during the previous century, the various Reformed Churches in the Netherlands that allowed women to take up offices in the Church, did so on hardly sound exegetical grounds. He says (translated from the Dutch original): "This justifies the conclusion that, to a great extent, the course of events regarding this matter depends upon the distinctive characteristics of each church. The basic arguments that might have been drawn from Scripture have really been dealt with in a rather superficial way. Biblical data dealing with the distinction between male and female in the church, as well as those dealing with the office and with the particular and general office as an integral part thereof, played only a marginal role in the discussions. This seems rather strange in the case of churches which officially claim to operate from the Bible as their base."

This article is the result of an MDiv thesis written by AMJ Leene with Prof Dr HJ Hendriks as her tutor.

AMJ Leene is a member of the Gereformeerde Kerk Vrijgemaakt in the Netherlands. In this Church all offices are closed to women. We wish to thank Prof J du Preez for translating this article.

As regards their exact point of view, no report has, as yet, been made public. However, a commission has been appointed in this regard, which, inter alia, has sent a questionnaire to the various churches. The new chairperson of the Gereformeerde Bond in the Protestant Church has stated that he is not even prepared to discuss this matter (cf Nederlands Dagblad 21.08.07 www.nd.nl.) This point of view is not restricted to the Netherlands alone. A good number of denominations in Africa hold the same opinion. 
At present, the discussions concentrate mostly upon the interpretation of a few Bible texts: the so-called 'zwijgteksten' ('silent texts') and on the Hermeneutic dimension. ${ }^{3}$ In our view, too little attention is being paid to an integrated understanding of a Trinitarian notion of God, theological anthropology, missional ecclesiology and paradigms. There are various reasons for the importance of once again paying attention to this matter.

Firstly, the question concerning the place of women in the church is important with a view to ecumenical cooperation, and the manifold differences of opinion in this regard (Volf 1998:221; Smink 2006:191). The relation between the theology of ministry (the offices in the church) and the doctrine of God is important in the ecumenical field, for it is precisely this doctrine that opens up worldwide possibilities (Smink 2006:195).

Quite apart from the question regarding the admission of women to the ministry, the second reason concerns the fact that discussions regarding the identity of, and leadership in, the church have recently become a matter of increasing urgency (Burger \& Wepener 2004; Roxburgh 2005:13; Van der Borght 2000:23,264; Fisher 1996:9; Van der Borght 2005:234). Questions about the role of the church in society and the identity of church leaders frequently come to the fore. These are important matters and have stronger links with the question about the role of women in the church than one would initially expect. In fact, these matters all concern women's leadership, for they assist in articulating this leadership, if they are good.

The third reason to be advanced is the following: sexual identity is still an important matter in- and outside the church. The past century testifies to the fact that significant changes and shifts have taken place as regards the identity of both men and women. Factors, such as the opening up of education to women, economic development, as well as birth control (contraception), have contributed greatly in creating a significant place for women in public life. The movement for emancipation in various areas of society has brought about striking changes in the position and composition of the family. Changing family compositions have resulted in families falling apart (Castells 1997:193,196-197,287294. ${ }^{4}$ The question concerning identity in the field of ecclesiology, leadership and anthropology is all about the Trinitarian God.

In our dealings with the question concerning the leadership of women within certain ecclesiastic structures, we firstly must ask the question about God, at least insofar as it touches upon ecclesiology and theological anthropology (Guder 1998:3; Folkers \& Verkerk 1998:202; Smink 2006:41), as the question about God is more important than what

\footnotetext{
Mainly those parts of Scripture are being discussed that seem to forbid women to speak in the church (or: in public worship), whereas those parts that seem to allow them to speak are not mentioned. This is especially noticeable in the report of the Christian Reformed Church in the Netherlands (Christelijk Gereformeerde Kerk). Naturally, exegesis is important. There is a need, however, for a broader look, one which will, for example, include anthropology and different forms of leadership. This implies that other parts of Scripture must also be considered.

4 This does not mean that emancipation, as such, has taken a wrong turn. However, it does bring about shifts that may lead to an identity crisis. During September 2006, discussions were held in Germany and the Netherlands during which it was alleged that emancipation has gone too far. (Cf Nederlands Dagblad of 15 September 2006: Kritiek op Vrouwenemancipatie, www.nd.nl), while a 2004 article contended that emancipation in the Netherlands is still far behind

(http://www.nd.nl/Document.aspx?document=nd_artikel\&vorigDocument=nd_zo ekresultaten\&id=45141). A plausible reason for such contrasting opinions is the fact that both women and men are still searching for a 'new' identity and, as a consequence, for a new role in society. Emancipation has often led to a double role for women, because men have not, as yet, emancipated themselves. On the one hand, this brings about an acceleration of the emancipation process while, on the other hand, it is true that this process has still not run its full course.
} 
concerns the church (Barth 1936:440; Küng 1967:7) or leadership. Thus, in order to come to a new understanding of women and church leadership, the authors of this article use it as the point of departure. With this in mind, they make use of a more integrated methodology that amounts to the following: in addition to seeking and obeying God's will in missional ecclesiology and theological anthropology, one must take into account certain contexts, as well as historical developments regarding women in the ministry. ${ }^{5}$

\section{Paradigms and Identity}

Over the centuries, context and culture have influenced the role of the church, the structures of leadership and the identity of both men and women. Armour and Browning (2000) explain this in the light of their 'system model,' which reveals to what extent our image of God, the role of the church, church leaders, men and women have changed through the ages. It points out that these matters are closely connected with, and influence, each other. One may also speak of paradigm changes. Paradigms are all about women in ecclesiastical leadership positions (Becker 1996:49; Armour \& Browning 2000:24-25). Shifting a paradigm normally involves an identity crisis. It challenges us to look for renewed obedience of God within a new paradigm in a certain context. It is important to know what precisely has changed, so that we may bear this in mind.

As regards the identity of the church, one can ascertain that the church has experienced a crisis during the past years as a result of changes in society, due to secularisation and pluralisation. Furthermore, the role of church leaders has undergone radical changes; they experience personalisation and clericalisation in their ministry (Heitink 2002:261). Their work has been broken up into small pieces (Burger \& Wepener 2004:11). Much is expected of them, but they no longer have the authority formerly associated with their office. ${ }^{6}$ It is precisely in times of change, that leadership is so important (Burger \& Wepener 2004:6).

This compels us to re-examine the identity of leadership that operates in a serving capacity. The most striking changes concern the position of women in society. Because, nowadays, women can study and, to a great extent, control their motherhood; they have become more independent and can care for themselves. These are striking changes compared with earlier times, when women played no role in public and were not perceived to be full human beings created in the image of God. ${ }^{7}$

Therefore, it should be clear that context and identity are closely connected to each other. But, it should also be clear that, due to changes and paradigm shifts, it is by no means easy to find one's identity.

This is all the more true when, as our point of departure, we take the authority of the Bible as the Word of God and as a revelation of who the Trinity is and how the Trinity acts in our lives. In our search for identity, we, as Christians and theologians, must find it in the Triune God who is a living God in every context and time. Truly, our point of departure is

5 For this inquiry, we have made use of Hendriks's (2004:9) methodology, which may be defined as an integrated missional and practical methodology.

6 The rapid transformation of society brings about increasing generation gaps, which make it all the more difficult to keep pace with such a society and still be able to understand each other.

7 One recalls Tertullian's opinion that women were the doorways of the devil and that they destroyed God's image (Lutz 1997:31). Augustine also believed that women were not equal to men and that men alone were the image of God (Küng 2001:29-30; Mickelsen 1986:21; Lutz 1997:32). As regards Calvin, there has always been a difference of opinion about his view on women (Tucker 1992:162; Küng 2001:67). Calvin acknowledged the spiritual equality of women towards their husbands, but also found a difference in status: women were placed second. 
never to be found in changing contexts and shifting paradigms. But, they do challenge us to search anew for the core of our identity and our faith.

\section{Trinity; Missional Ecclesiology}

The point of departure for the identity of the church is to be found in the Triune God who reveals Himself in his Word. Different processes, for instance ongoing secularisation, influence the present (social) context. This challenges us to question anew the identity of the church. By means of this context and by reading the Bible, we discover that, most profoundly, God is a missional God, the missio Dei. Mission is not a task for the church, or for a certain commission, it is God's own work. Karl Barth (1957:101-126; Hendriks 2004:25) was one of the first theologians ${ }^{8}$ to impart new significance to mission by, firstly, neither dealing with it in the context of ecclesiology nor in the context of soteriology, but by placing it primarily in the context of the Trinitarian dogma so that, now, mission is no longer to be viewed as a subdivision of the church, but is to be valued as her deepest identity.

This does not imply attenuation or structuring of who God is, as though the Trinity is only missional. However, to be missional belongs to the most profound nature of God. God craves for a relationship with people, reaching out to them. This is clearest understood by God's sending of the Son, Jesus Christ, as Saviour. The church is a community institutionalised by God (Barth 1962:334). Therefore, the Triune God's mission is identical to the church's mission, which, in fact, is the purpose for its existence. Trinitarian relationships can serve as a model ${ }^{9}$ for the institution of the church, because the triumphant God is present in the church through the Holy Spirit who moulds the church into the Triune God's image (Volf 1998:239). Furthermore, the doctrine of the Trinity points to unity and diversity.

Comment should be delivered upon the corresponding analogy of unity and diversity between Trinity and the church/creation: "The unity of the creature can never correspond to the mysterious unity of the triune Creator" (Volf 1998:192, quoting Peterson: 'Monotheismus' 104). The point at issue is the correspondence (Dutch: 'correspondentie') that proceeds not only straight from above (Trinity) downwards (church and society). Thinking in terms of the correspondence between church and Trinity means nothing more than thinking that has theological consequences (Volf 1998:194). Therefore, it is indeed possible to speak of a form of unity between the Trinity, on the one hand, and church and creation on the other. The church participates in the Triune God, for it is its foundation in

$8 \quad$ Voetius (1588-1676) was the first Protestant theologian to develop a theology of mission (Bosch 1991:256). History recognizes also a few other individuals in this regard (Bavinck and Blauw), but the theology of mission has never received much attention.

$9 \quad$ Smidt-Leukel (2002:57) comments on a Trinitarian model for mission by alleging that there is no such model. He gives two reasons: " 1 . The most distinctive features of different missiological concepts do not depend on a Trinitarian or nontrinitarian model, but on the theology of religions for which their proponents opt. 2.

Trinitarian theology in general is not confined to any one of those options.” He rather opts for an exclusivistic and inclusivistic or pluralistic platform together with a trinitarian model. According to him, there is no single model, but a number of interpretations of the trinitarian formula and, consequently, a number of trinitarian models (2002:63). Greene and Ward react to this view and conclude that Smidt-Leukel totally misunderstands the 'metaphor' concept (Ward 2002:73). We propose that there are indeed different angles of incidence in our use of Trinity as model. However, these are yet to be thoroughly explored (Volf 1998:192-195). 
baptism that leads believers into communion with the Trinity and with the fellowship of the church. ${ }^{10}$

The Father's sending of the Son, and both the Father and the Son's sending of the Holy Spirit reveal something about unity as well as diversity. Every 'person' has his/her own role to play within this unity. The church imparts form to this unity and is the body of Christ. Although the church is one body, it contains a diversity of spiritual gifts and persons (1 Cor. 12). Within this Trinitarian-missional frame, the question about women in the ministry comes to the fore once more (Bosch 1991:472). How this happens will be seen later. The church is commissioned to participate in God's mission by being a place of unity, as well as one of diversity. In this way, it reflects something of God and thereby something of her true identity. Within the community, there is no question of ethnicity or sex (Gal. 3:28). ${ }^{11}$

\section{Trinity; Theological Anthropology}

The doctrine about God and anthropology are intertwined. While asking about humankind and its calling, the question about God should also be asked (Prince 2002:308). When speaking of humankind's identity, one must look at the Creator. A Trinitarian anthropology not only assists us in our understanding of who humans really are, but it also assists us in understanding their calling (Prince 2002:308). The doctrine of Trinity is of great importance for theological anthropology (Torrance 1996:1). Both male and female represent God's image, which means that both male and female form the basis of the Imago Dei (Barth 1960:289, 292,306-308, Genesis 1:27). The doctrine of Trinity discloses that, in God most profound nature, God is relational. Trinitarian theology is a theology of relationships, "which explore the mysteries of love, relationships, personhood and communion within the framework of God's self-revelation in the person of Christ and the activity of the Spirit" (LaCugna 1973:1). However, God is no model for gender identity. ${ }^{12}$ Gender differences are the result of sexual differences and social contexts (Volf 2003:169). ${ }^{13}$

10 Biblical passages in this respect are: John 17:21: "That all of them may be one, Father, just as you are in me and I am in you" (NIV); Matthew 18:20: "For where two or three come together in my name, there am I with them (NIV); Galatians 2:20: "I have been crucified with Christ and I no longer live, but Christ lives in me" (NIV).

11 It is evident in the so-called 'silent texts' how authors take the missional context into account. Women are acquainted with freedom and equality in the church. But, as regards the missional context, they sometimes have to be content with a subordinate role which for the rest holds good for all Christians, namely that of being a servant. Today the question about women in the offices of the church is to be asked anew, but now in an emancipated context. What do non-Christians think when they see that women do not receive their rightful place in the church? This is not our point of departure, but it does play a significant role, also in the Bible. See 1 Peter 3:1-7 and 1 Corinthians 14:35.

12 This argument is based on the article by Volf (2003:155-178): “The Trinity and gender identity” in Gospel and gender: A Trinitarian engagement with male and female in Christ. The first problem is if we take Trinity as a gender point of departure, it involves the names of the Trinity. Many feministic theologians opine that this is all about the question of equality between male and female, because (so it is argued) if God is a male, then it is a male who is God. We shall not probe this particular matter any further. (For this, see Volf 2003:157-164 and Torrance 2003:179-197). In this article we still use traditional language. To use feminine words for God does not solve the problem. But we acknowledge that language regarding God is important and a difficult issue. We firstly believe that God is not sexual. This reveals the importance of language in a discussion such as the case in hand. However, this is not what really concerns us here. What actually concerns us is how the Trinity is structured.

13 Nonetheless, the question remains what these differences really amount to. We know that we deal with paradigms, perceptions and cultures. Yet, we must acknowledge that there are more differences than only sexuality and that none of these are per se a question of 'authority.' 
Males and females are in the image of God in their shared humanity. Here, the importance of unity and variety also come to the fore. Theological anthropology certainly has something to say with regard to the relationship between male and female. Regarding the relationship between the Triune God and humanity, it is of the greatest importance to realise that there is no hierarchy in the doctrine of Trinity, which may make women subordinate to men. On the contrary, the doctrine of Trinity provides a structure that secures equality. ${ }^{14}$ The identity of both the male and female rests in the Triune God who not only sends men, but also women. Nobody can be sent as an individual. There is cooperation within the body, without which there is no unity. Within this body, everyone has an own identity in Christ.

Of course, one must consider the differences between the male and female. However, these do not imply that women are subordinate to men. On the contrary, they imply that males and females complement each other. We must reckon with the Fall. From that time onwards, the relationship between men and women has become more problematic, as men are inclined to dominate women. ${ }^{15}$ They do not want to be dependent upon women (i.e. allow women to be the aid suited to them), while women want to manipulate men and desire them. But, since Christ's coming, everything has changed. The unity and equality between the male and female attains a concrete form in the congregation (Mickelsen 1986:109). Only by means of diversity within unity can male and female represent God's image and fulfil their task. In respect of males and females, missional ecclesiology and theological anthropology influence our view on leadership in the church. That is how it is, simply because unity in diversity takes a central place within the Trinity.

\section{Missional and Serving Leadership by Both Men and Women}

\section{Trinitarian ministry}

A missional ministry is always and primarily Trinitarian (Purves 2004; Bosch 1991; Goheen 2000). It is God who calls and sends, Christ who provides a new identity, and the Spirit who metes out gifts to everyone, irrespective of sex.

"Church and office do not exist by themselves; they receive their significance only within this Trinitarian context. Such an approach to church and office in light of the missio Dei creates abundant space to experience the office and to understand it in terms of vocation" (Van der Borght 2000:482 - translated from the Dutch original). Therefore, guidance does not exist in isolation, but takes place in the context of Trinity and as a service to the congregation. Within this framework, the apostleship of believers is emphasised once more. God calls everyone.

Our entire view on the church's ministries would improve if we could focus on the need of the church in her mission to the world instead of emphasising those who provide guidance (in terms of gender, ethnicity and social class) (Kanyoro 1997:25). Within this Trinitarian context, the concepts of diversity and unity regarding leadership become

14 Barth holds another opinion in this regard. According to him, women are indeed subject to men and females have been given males. In support of his view, he makes use of the doctrine of Trinity. For Barth (1960:291), the relationship between male and female is based in the covenant between God and Israel, and thereafter between God and the church. For Barth (1960:291), it is of paramount importance that God did not create a human to be lonely [or to stay alone]. He does not probe the question regarding the office in the church and the relationship between male and female. He pays special attention to sexuality as expressing the difference between male and female. As regards equivalence, he says very little.

15 We see this in different forms, sexual, emotional, financial and much more. 
important once more. In this connection, relations come to the fore in which everyone, whether male or female, each with his or her unique gifts, feels called upon to work together in unity. The Bible tells us how God calls upon both women and men to witness for him. ${ }^{16}$

\section{Authority and Service}

Therefore, authority rests in God, whatever the calling may be. And, as regards our subject under consideration, this holds good specifically in the case of guidance in a serving capacity. The question of authority has always been the biggest and most important problem as far as female guidance is concerned (Becker 1996:23).

According to the Bible, leadership or guidance always means service (Stott 2006:9; Smink 2006:122). Therefore, this should be emphasised in a missional ministry.

"In case of an office in which teaching and governing dominate, women are not considered for office. But, in the case of an office that is of a serving nature a huge blockade regarding the throwing open of the office for women has been removed without any further ado” (Lim 2001:169, translated from the Dutch original).

This does not mean that authority has now become less important. However, it does mean that we must take a different look at authority. ${ }^{17}$ Now, it will be a question of authority as a relationship: authority related to the Triune God and to the congregation in unity and diversity. Authority does not imply hierarchy, as the doctrine of the Trinity excludes this. Authority rests in the commission, and does not rest in the difference between male and female. To govern is not, by definition, a typical male concern (Graafland 1999:218). ${ }^{18}$ In any case, men and women have different views on power (Nuechterlein \& Hahn 1990:23). ${ }^{19}$

\section{Leadership Structures and Context}

As said previously, the context regarding leadership also plays an important role. This is evident in the Bible, as well as, for instance, in Calvin's works (Heitink 2002:30,272; Smink 2006:164; Stott 2006:109; Graafland 1999:333). Ecclesiastical structures ('ambtstructuren') as known today are not directly derived from the Bible. In other words, the Bible does not mention a cut and dried leadership model (Volf 1998:245). In the course of time, the trio (minister, elder, deacon) has, to such an extent, become a dominating factor

16 According to the Bible, women are called upon to become apostles and deacons. A study of church history points to the striking fact that many women have served as missionaries (Doornenbal 2006; Lutz 1997). It seems as though home churches ('thuiskerken') needed another type of authority than that exercised in the missionary field. Many people find it quite acceptable for a lady to preach in the missionary field, but disapprove of her preaching in the home church. This indeed is a strange way of thinking. However, it shows that women receive more space within a missional context.

17 During the time of the Reformation, fear of the abuse of power played an important role in making decisions regarding the office in the church (Van der Borght 2000:474).

18 Graafland (1999:218) accepts a mother's 'motherliness' and her caring for the family as a form of governing. And, since one may regard the congregation as a family, why not regard these female forms of governing as on a par with the church offices? Graafland makes use of an old paradigm in which especially the so-called 'shepherd' model, which emphasises care, still functions. But, nowadays, in the missional church this model has negative connotations, although it must be pointed out that a caring dimension always remains in the ministry. By emphasising motherliness, Graafland indeed introduces an interesting aspect of ministry. However, this may not be stereotyped by claiming that men know nothing of the caring aspect of ministry, as that would imply that they are unable to exercise the caring side of ministry.

${ }^{19}$ Men are more power-directed, while women are more relation-directed (Tannen 1991:24-25). 
in establishing the identity of the offices within the Reformed tradition that it has become difficult to deal with them in a creative way. One easily becomes bogged down in these three offices, as if they are the only possible ones, so that nothing else in the church is allowed to obtain any official status (Van der Borght 2000:365). The church is inclined to defend existing structures, and consequently it experiences difficulty in initiating a process of renewal, despite the Bible, as well as the context, calling for such a process (Smink 2006:263). The church is frequently commissioned to find the proper identity of leadership in a certain juncture of time and context. Therefore, the church is continuously called upon to find new forms of guidance within a missional ecclesiology and a theological anthropology in a new paradigm. ${ }^{20}$

\section{Women and Men Working Together}

The Bible and the doctrine of the Trinity, as well as our present context, challenge us to move towards a new paradigm in which men and women complement each other by way of service and cooperation, because they are being called by God, have received their identity in Jesus, and have been entrusted with the Holy Spirit's gifts in order to be equipped for the task of being God's witnesses in the world. In this way, both men and women represent the image of God as a unity in diversity. "The synergism of male and female working together represent the completed creation of God, when he looked at male and female and saw that all he had made was 'very good'”' (Gen 1:31) (Lutz 1997:235).

However, this is easier said than done, because more is needed than to accompany men in leadership in order to create new styles of leadership that would include female, as well as male, features. ${ }^{21}$ Such a paradigm shift would require a totally different kind of authority, namely, one not based on hierarchy (Becker 1996:69). Furthermore, we need a paradigm shift in respect of our views on the church and theological anthropology. This would be radical in the biblical sense of the word, as this would ensure women of their rightful place and give the church, as well as male and female leaders, their true identity. Even if women would be allowed to take office, it would still be important to ensure structures of leadership and theological anthropology. We should not too soon conclude that everything would be in order now. It must further be sorted out how men and women could receive their rightful places in a missional ministry, while working together without ignoring sexual differences. It is a matter of cooperation in a search for the right kind of identity and for everyone’s rightful place.

\section{Conclusions}

In this article, we have endeavoured to explain briefly three issues regarding identity and the Trinity. Firstly, the identity of the church is founded on the Triune God to whom the missio belongs, in which no hierarchy exists and in which diversity and unity are key words. Simply because God is a relational God, unity and diversity are clearly important. Regarding theological anthropology, identity is also of enormous importance. The human

20 Calvin spoke of 'the need of the times.' He admitted that the offices with which he dealt were not directly derived from the Bible. This implies that he accounted for his own times. Sometimes, the church is so afraid to change things. For Calvin, the question of women's role in the church belonged to the so-called adiafora: things subject to change (Douglass 1993).

21 De Boer (2006) proposes a special office for women. Our comment on this proposal would be that it still does not solve the problem of authority. Moreover, De Boer's proposal still functions within an old paradigm that, to our mind, is no longer relevant. 
being (male and female) is created in the image of God (imago Dei) in order to form a unity within diversity. Thus, although God is no model for sexual identity, the identity of men and women is found in the Triune God. Due to the Fall authority began to play an important role. But, as the Trinity excludes hierarchy, authority should not be our point of departure. Missional ecclesiology and anthropology both ask for new forms of leadership in which women have a place equivalent to that of men. Not authority, but service ought to be the distinctive feature of this missional ministry. Authority is founded in God alone. He sends; in Christ we find our new identity, while the Holy Spirit presents gifts that, without being sexually directed, enable us to be God's witnesses in the world. From this perspective it is wonderful to see that men and women have been created in such a way as to complement each other and, in this way, represent God's image. The search for identity in a new paradigm is extremely important but not something new. Seeking this identity in the Triune God may appear to be an easy answer. Yet, in practice, it is much more difficult to enable people to understand that our identity is to be found in the Triune God, because it depends upon our understanding of a Trinitarian theological anthropology and missional ecclesiology that should become visible in our ecclesiastical structures. We believe, however, that if this is understood in an integrated way, with men and women together as equal partners in God's mission, all facets of our lives would become a reflection of the Triune God.

\section{BIBLIOGRAPHY}

Armour, J 2005. Living Trinitarian faith: A restructured theology of the ordained ministry. Forum for Theology in the World, 8/2, October, pp. 112-124.

Armour, MC \& Browning, D 2000. Systems-sensitive leadership: Empowering diversity without polarizing the church. College Press: Joblin.

Barth, K 1936. Church dogmatics volume I: The doctrine of the Word of God, part 1. T\&T Clark: Edinburgh.

Barth, K 1957. Die Theologie und die Mission in der Gegenwart, in Theologische Fragen und Antworten, pp. 100-126. Evangelischer Verlag: Zollikon.

Barth, K 1960. Church dogmatics volume III: The doctrine of creation, part 2. T\&T Clark: Edinburgh.

Barth, K 1962. Church and theology. An address given $7^{\text {th }}$ October 1925 at the Göttingen Autumn Conference, and $23^{\text {rd }}$ October 1925 at the Theological Week at Eberfeld, in Theology and church, the preacher's library, pp. 286-306. SCM Press: Bloomsbury Street London.

Becker, CE 1996. Leading women: How church women can avoid leadership traps and negotiate the gender maze. Abingdon: Nashville, Tennesee.

Borght, van der Ed, AJG 2000. Het ambt her-dacht, de gereformeerde ambtstheologie in het licht van het rapport Baptism, Eucharist and ministry (Lima 1982) van de theologische commissie Faith and Order van de Wereldraad van kerken. Meinima: Zoetermeer.

Borght, van der Ed, AJG 2005. To be or not to be - the identity of the minister in terms of his office within the reformed tradition. NGTT 46, March/June, pp. 234-246.

Bosch, DJ 1991. Transforming mission: Paradigm shifts in theology of mission. Orbis: Maryknoll, N.Y. 
Burger, CW \& Wepener, CJ 2004. Die predikantsamp deel 1: Onduidelikheid oor die kerninhoud van die predikantsamp. NGTT 45/1 Maart \& Junie, pp. 6-14.

Burger, CW \& Wepener, CJ 2004. Die predikantsamp deel 2: Op soek na 'n Bybelse visie van die amp: Ironieë en verrassings. NGTT 45/1 Maart \& Junie, pp. 15-22.

Burger, CW 2004. Die predikantsamp deel 4: Predikantwees in die Gereformeerde tradisie in die 21ste eeu - nuwe uitdagings en nuwe tendense. NGTT 45/2 Maart \& Junie, pp. 529-537.

Burger, CW 2004. Die predikantsamp deel 5: Kan die drie-ampteleer ons help om 'n Bybelse fokus aan die predikantsamp te gee? NGTT 45/2 Maart \& Junie, pp. 538-548.

Castells, M 1997. The power of identity, the information age: Economy, society and culture, volume II. Blackwell: Malden Massachusetts.

De Boer, EA 2006. Zij aan zij, pleidooi voor een vrouwelijk ambt in de kerk. De Vuurbaak: Barneveld.

Dekker, G 1995. Als het getij verloopt ... opstellen over godsdienst en kerk. Ten Have: Baarn.

Doornenbal, R 2006. Christelijk leiderschap door Evangelische vrouwen. Ellips (10 Juli).

Douglass Dempsey, JS 1993. Vrouwen en de christelijke vrijheid bij Calvijn. Kok: Kampen.

Fisher, D 1996. The 21st century pastor: A vision based on the ministry of Paul. Zondervan: Grand Rapids, Michigan.

Folkers, H \& Verkerk, MJ 1998. Vrouwen op een Zij spoor? Emancipatie van de vrouw en het verstaan van de Schrift in gereformeerd perspectief. Buijten \& Schipperheijn: Amsterdam.

Graafland, C 1999. Gedachten over het ambt, 'Och, of al het volk des HEEREN profeten ware ...!' Boekencentrum: Zoetermeer.

Goheen, MW 2000. As the father has sent me, I am sending you. J.E. Lesslie Newbigin's missionary ecclesiology. Zoetemeenr: Boekencentrum.

Guder, D 1998. Missional church: A vision for the sending of the church in North America. Eerdmans: Michigan.

Heitink, G 2001. De biografie van de dominee. Ten Have: Baarn.

Hendriks, HJ 2004. Studying congregations in Africa. Lux Verbi: Wellington.

Kanyoro, MRA 1997. In search of a round table, gender, theology and church leadership. WCC Publications: Geneva.

Küng, H 1967. De kerk. Paul Brand: Hilversum.

LaCugna, CM 1991. God for us: The Trinity and Christian life. Harper: San Francisco \& New York.

Lim, K 2001. Het spoor van de vrouw in het ambt: Theologie en geschiedenis. Kok: Kampen.

Lutz, L 1997. Women as risk-takers for God. EF: Cumbria.

Mickelsen, BA 1986. What does kephale mean in the New Testament? In Women, authority and the Bible. Intervarsity Press: Downers Grove.

Nuechterlein, AM \& Hahn, CA 1990. The male-female church staff, celebrating the gifts, confronting the challenges. Alban Institute: New York. 
Price, DJ 2002. Karl Barth's anthropology in light of modern thought. Eerdmans, Grand Rapids Michigan: Cambridge.

Purves, A 2004. Reconstructing pastoral theology: A christological foundation. Westminster John Knox Press: London.

Roxburgh, AJ 2005. The sky is falling: Leaders lost in transition. ACI Publishing: Eagle Idaho.

Smink, GJ 2006. Het kerkelijk ambt naar een nieuw paradigma: De ambtstheologie van Hans Küng. Boekencentrum: Zoetermeer.

Stott, J 2006. Christelijk leiderschap, bijbelse modellen voor kerk, evangelie en bediening. Novapres.

Tannen, D 1991. You just don't understand women and men in conversation. New York: Ballantine.

Torrance, AJ 1996. Persons in communion: An essay on Trinitarian descriptor and human participation with special reference to volume I of Karl Barth's Church Dogmatics. T\&T Clark: Edinburgh.

Torrance, AJ 2003. 'Call no man father!’: The Trinity, patriarchy and God-talk, in Gospel and gender, a Trinitarian engagement with being male and female in Christ. T\&T Clark: New York, pp. 179-197.

Volf, M 1998. After our likeness: The church as the image of the Trinity. Eerdmans: Grand Rapids.

Volf, M 2003. The Trinity and gender identity, in Gospel and gender: A Trinitarian engagement with being male and female in Christ. T\&T Clark: New York, pp. 155-178. 